\title{
DEVELOPING CROSS-BORDER COOPERATION IN HIGHER EDUCATION: RESEARCH OF DIRECTIONS
}

\author{
Lyudmila Sukhorukova $^{1 *}$, Nikolay Fokin ${ }^{2}$, Tatyana Shestakova ${ }^{3}$, Aleksandra \\ Shestakova ${ }^{4}$
}

\author{
${ }^{1}$ Prof. Dr., Southern Federal University, Russia, Isuhorukova@sfedu.ru \\ ${ }^{2}$ Assist. Prof., Southern Federal University, Russia, nfokin@sfedu.ru \\ ${ }^{3}$ Assist. Prof., Southern Federal University, Russia, tshestakova@sfedu.ru \\ ${ }^{4}$ Southern Federal University, Russia, ashestakova@sfedu.ru \\ ${ }^{*}$ Corresponding Author
}

\begin{abstract}
Relevance of transboundary and cross-border cooperation in higher education in Russia is conditioned by the state policy of complex development of border geostrategic territories in conditions of development of globalization, regionalization, growing migration flows of population, including families with children, educational mobility of students. The main idea is that nowadays a high level of conceptualization of crossborder cooperation in the training of pedagogical and managerial personnel in the sphere of education in the border area of Russia as an integral scientific and educational system is required. The aim of the research is to substantiate the research directions of managerial and pedagogical personnel training in the sphere of education, migration management in cross-border university cooperation until 2030. The methodological basis of the research is the interdisciplinary paradigm of analysis of cross-border and cross-border cooperation in education. We examine and summarize research on cross-border cooperation in education from 1993 to 2020, conduct a systematic search for theories of state border protection, borderology, discuss the results and implications for educational research and practice. The study used a content analysis of relevant 313 empirical studies published between 2017-2021, in journals included in international databases Scopus, Web of Science, and Google Scholar, Elibrary-RINC. Research methods: theoretical analysis of psychological and pedagogical literature on the problem of research; method of modeling, design and search experiment; bibliometric methods; questioning; content analysis, expert evaluation. In our research theories, models, prospects, potentials of cross-border cooperation in the global and transboundary dimension were studied, the results of interdisciplinary study of cross-border cooperation in borderology and political science were presented. The theories, problems and models of cross-border cooperation of higher educational institutions in the post-Soviet period are highlighted. The most significant results: a) the necessity of creating potentials of federal universities to develop cross-border geostrategic cooperation in the field of education was substantiated; $b$ ) conditions and possibilities of development and implementation of master's programs of training of educational leaders relevant to the formation of cooperation with universities of border and cross-border space were systematized; c) research and educational problems of research of border and cross-border cooperation were developed. The study concludes with a discussion and formulation of new research directions of research on cross-border and transboundary cooperation in education. Information about main directions of research of transboundary and cross-border cooperation can be used when planning new scientific, educational and methodological projects.
\end{abstract}

Keywords: cross-border cooperation in higher education, federal university, education management, teaching staff.

\section{INTRODUCTION}

Taking into account the processes of globalization, the modern type of international relations is cross-border. 
The last decade has seen the development of interest in the social functions of state borders and their influence on the social and cultural environment of border territories. Among the variety of directions of international and interregional cooperation of post-Soviet countries there is an active development of cooperation of universities in the field of border space, development of international and border cooperation concepts both along the borders of the Russian Federation and the CIS, SCO, BRICS, etc. This is since Russia is an important link in the integration of the Commonwealth of Independent States (CIS) into the global community. The Russian Federation is also the main destination for both permanent and temporary migrants from other CIS countries, including migrant families with children, and student migration is developing.

The development of cooperation between border areas of neighbouring states, on the one hand, contributes to improving the livelihood of the population of border territories and maintain historically established contacts in social, cultural, informational, and other spheres, on the other hand, affects the formation of the much-needed "belt of good neighbourliness" along the perimeter of Russian borders. The development of this type of activity is conditioned by the Concept of cross-border cooperation in the Russian Federation (approved by the Order of the Government of the Russian Federation No. 2577-r of October 7, 2020).

The concept defines that the cross-border cooperation is carried out considering the existing prospective economic specialization of the regions in accordance with the Strategy for Spatial Development of the Russian Federation until 2025 (SPR). In the SPR there is a special type of territories, which will receive increased attention in public policy - "geostrategic border territories of the Russian Federation". Their list includes constituent entities of the Russian Federation, which are border territories, but at the same time are not included in the number of "priority geostrategic territories of the Russian Federation". Role of border regions strengthening as geostrategic territories in the spatial development of the Russian Federation actualizes new research and educational projects, considering the intensity of educational migration, formation of cooperation with the former Soviet republics.

For successful realization of the cross-border potential cooperation it is necessary to introduce into the public consciousness modern views of cross-border contacts as a complex system-forming mechanism, which, depending on local conditions, can be used to solve various socio-economic and political problems. The development of cooperation between border areas of neighboring states, on the one hand, contributes to improving the livelihood of the population of border areas and the maintenance of historically established ties and contacts in social, cultural, informational and other spheres; on the other hand, it affects the formation of the much needed "belt of good neighboring " along the perimeter of Russian borders. Cross-border cooperation is a mechanism for advancing the social and educational agenda and, at the same time, strengthening the capacity of participating universities.

In this project the authors rely on an interdisciplinary approach, assuming that the potential for interaction and the real level of cooperation of a border region with a neighboring territory, on a par with the internal conditions of the border region itself, is also determined by the functional role of the state border. Vardomsky L.B. distinguishes three basic functions of the border: contact (connecting), filtering (for example, at the customs border) and barrier (hindering communications) (Vardomsky, 2008, p. 90). The border factor has a significant impact on the further development of education and science. Border factor influences on the Southern Federal University in particularly, as it is the part of newly formed consortium "Rubezhi Rossii" (Ivanov, 2020).

Boundaries are closely related to the issues of statehood preservation, security, economy, social sphere, including education and science. The problem predetermined the purpose of the study. The aim of the study is to identify research trends in the development of cross-border cooperation in higher education for the period up to 2030 and to identify understudied aspects of the problem.

The key research objectives were the following: development of research directions of scientific and educational activities in the border area of the South of Russia as an important geostrategic territorial border; training of management personnel in education, additional professional education of teaching staff, migration management in education. To solve these problems and objectives on the material of domestic and international research, the most promising areas of scientific research was studied and insufficiently studied aspects of the issue of cross-border cooperation in education in the relevant content is management personnel training in the field of education were identified.

It is suggested as a working hypothesis that the Southern Federal University (SFU) has the scientific and educational potential to expand cross-border cooperation in the border and cross-border space of Southern Russia. We examine and summarize research on cross-border cooperation in post-Soviet education from 
1993 to 2020 and discuss the results and implications for educational research and practice. Research has been conducted, selected results of which are offered in this article.

\section{METHODOLOGY}

The methodological basis of the study is:

- Borders in the global world (Vardomsky L.B., Nogmova A.S., Komleva V.V., Kotilko V. N., Lukichev G., etc.);

- Giving education the status of a social institution (Volkov A.E., Durkheim E., Mudrik A.V., Parsons T., etc.);

- Modern native educational systems management concepts (Konarzhevsky Y.A., Lazarev V.S., Moiseev A.M., Potashnik M.M., Tretiakov P.I., Shamova T.I., etc.);

- Personality-oriented approach, which considers the subject of education as an integral personality with its biological, social and spiritual components (Bondarevskaya E.V., Yakimanskaya I.S., etc.).

Theoretical foundations are provided by the theories of sustainable development of global and regional social systems, education; theories and models of frontier space; theories of frontier, borderland, border security, ideas of country studies in the educational systems of borderland. The evaluation and selection of relevant research was carried out according to selected criteria such as systematization, description and analysis of selected materials, summarization - analysis of results, establishment of research trends. In addition, a systematic search for theories of state border protection, borderology, discuss the results and implications for educational research and practice of higher education development.

We identified relevant literature using a multi-thematic, multi-step keyword and phrase search strategy. (313 sources relevant to our query). The list of key concepts of cross-border cooperation comprised 17-word combinations: border territory; border geostrategic territory; border space; cross-border cooperation in the post-Soviet period; cross-border cooperation of universities; border university; cross-border cooperation of universities of Southern Russia; cross-border educational development; university networks and associations of border universities; border cooperation; border space; cross-border cooperation.

\section{RESULTS AND DISCUSSION}

UNESCO's work in developing the Thematic Initiative on the Future of Education is important for understanding the goals, objectives, and content of cross-border education and cross-border cooperation in education. This initiative is a catalyst for global debates about how knowledge, education and learning need to be rethought in a world of increasing complexity, uncertainty and instability (UNESCO, 2021). The Initiative is producing the UNESCO Global Report on Education, "The Future of Education: Learning to Be," which presents the challenges that lie ahead. The working papers for the report note that higher education as it exists today has reached its limits. The "Future of Higher Education" project is being developed by the UNESCO Institute for the Development of Higher Education (IESALC), inviting the scientific community of the world's universities for this project activity. This project on the future of higher education will stimulate creative and imaginative thinking and ideas about the future of higher education until 2050.

The project will innovatively shape several new perspectives on the future of higher education:

- Universities must become, in the broadest sense of the word, an ecological universities, i.e., connect with its major ecosystems - knowledge, social institutions, nature, economy, culture, individual learning, and the state;

- In recent years such phenomena as increased access to higher education appeared, changing the way in which higher education is financed, due to the growth of private providers and the privatization of publicly funded higher education, and the development of accreditation systems;

- Challenges and opportunities to external higher education systems include demographic shifts, political change, economic crisis, war and conflict, and global pandemics.

Universities face the daunting task of rapidly changing business models, including adjusting university structure, retraining staff, and streamlining teaching and research program, while at the same time struggling to preserve the university's mission as the heart of research, innovation, and entrepreneurship. By 2050, the content of higher education should become more global in nature. Disciplines will merge into a single field of interest. New areas of specialization will emerge as content becomes more humanized and relevant to the needs of global citizens. Globalization, massification of higher education by 2050 in societies with high participation rates of $60-90 \%$ will be achieved in most countries, which will actualize cross-border 
connections in higher education.

In the conditions of modern transformation of states, the role of regions as participants of international relations and ties is increasing. Cross-border cooperation acquires a special significance. Sustainable development of cross-border cooperation is determined by strategic plans, projects and programs of socioeconomic development, among which projects of cooperation in education in the border and cross-border space are topical. The intensification of cross-border cooperation processes is also realized by the increasing attention to the regional educational systems, universities, which is a multidisciplinary potential, the innovative "points of growth" in the development of cross-border cooperation in education are federal universities, including the South Federal university of Russia.

The institutionalization of cross-border cooperation, cross-border interactions can reduce their dependence on the geopolitical conjuncture, turn them into a factor of stabilization of the international situation in the geostrategic territory, provide important needs of borderland residents. For this purpose, a new program approach to cooperation for cross-border and border cooperation is being formed. The changes taking place on the political map of the world, the development of globalization, political instability, international and ethno-confessional conflicts, the migration activity of the population and students give special relevance to the humanitarian component of international relations in the border area.

The most important components of the border region's potential include its educational potential, first, the university network of higher education, its educational and scientific potentials (Kotilko, 2016, p. 253). Modern studies of border space and cross-border cooperation use an interdisciplinary approach and for this purpose refer to the fundamental developments in political science, international relations theory, geopolitics, sociology, political geography. The authors undertook a scientific analysis of publications on interdisciplinary problems of the essence and organization of border space:

- In limology, borderology as a border geostrategic territory;

- Analysis of barrier and contact functions of the state border;

- Domestic and foreign studies on the problems of cross-border university, cross-border cooperation, etc.

Among the variety of areas of international and interregional cooperation of post-Soviet countries, it is actively developing cooperation of universities in the field of cross-border and cross-border space. Significant projects of universities of the Russian Federation in the field of cross-border cooperation are: CIS (Pshenko, 2001), SCO, BRICS universities: CIS basic educational organizations, educational programs of double diplomas; holding a school "Interregional cross-border cooperation" and cross-border strategic debates; Internet conferences; open access to materials and the possibility of remote discussion; consortia of border universities (such as " Rubezhi Rossii ", etc.); Border Belarusian-Russian-Ukrainian University. These and other forms of cooperation show that universities should become the main catalysts of integration processes in the development of educational and scientific border area of the CIS and southern Russia.

The analysis based on publications in the field of border studies, mainly of the last decade, to trace the impact of globalization on the nature, functions, and regime of state borders, to assess the changing role of the state in their management were done. The analysis was undertaken to examine what are the main directions of development of cross-border cooperation in education, established models and practices of the sphere of education and science scientific potential, experience of the Southern Federal University (SFU) in the professional training of educational leaders (master's level). The authors use the principles of comparativism, mosaicism (multidimensionality of social phenomena), characterizing modern paradigm bases of humanitarian and pedagogical knowledge (table 1).

Table 1. Literature search and analytical categories: initial topics of analysis

\begin{tabular}{|c|l|}
\hline $\begin{array}{c}\text { Topics of articles and } \\
\text { number of articles }\end{array}$ & \multicolumn{1}{|c|}{ Leading Ideas of Scientific Analysis } \\
\hline $\begin{array}{c}\text { Socio-economic sphere - } \\
116\end{array}$ & $\begin{array}{l}\text { The concept of cross-borderness. Cross-border cooperation } \\
\text { contributes to the development and strengthening of } \\
\text { economic, cultural and humanitarian ties between the } \\
\text { border territories of the Russian Federation and neighboring } \\
\text { states. Inclusion of Russian territories in a number of Euro- } \\
\text { regional formations. }\end{array}$ \\
\hline
\end{tabular}




\begin{tabular}{|c|l|}
\hline $\begin{array}{c}\text { Spatial analysis of the nature } \\
\text { and levels of development of } \\
\text { districts in the Russian } \\
\text { Federation - 72 }\end{array}$ & $\begin{array}{l}\text { The main part of the border regions of the Russian } \\
\text { Federation currently belongs either to backward or } \\
\text { depressed regions. Russian regions play an extremely } \\
\text { important role in the process of cross-border interregional } \\
\text { cooperation. Forms of state support of border regions. }\end{array}$ \\
\hline Humanities -12 & $\begin{array}{l}\text { The concept of the state policy of the Russian Federation in } \\
\text { the field of training national personnel for foreign countries } \\
\text { in Russian educational institutions. }\end{array}$ \\
\hline Border - 25 & $\begin{array}{l}\text { The peculiarity of the geopolitical position of modern Russia } \\
\text { is multi-vector, which is reflected in its global strategy. There } \\
\text { are several vectors of relations - European, Asian and post- } \\
\text { Soviet, which predetermines the development of the model } \\
\text { "Russia as a Eurasian bridge of the global economy. }\end{array}$ \\
\hline Frontier - 32 & $\begin{array}{l}\text { The Frontier is characterized as an "unstable equilibrium } \\
\text { zone. }\end{array}$ \\
\hline $\begin{array}{c}\text { Experience of interuniversity } \\
\text { cross-border cooperation - }\end{array}$ & $\begin{array}{l}\text { Maximum use of the unique features of the region's } \\
\text { educational and scientific systems in order to organize and } \\
\text { implement in the border and cross-border space. }\end{array}$ \\
\hline $\begin{array}{c}\text { Formation of regional cross- } \\
\text { border scientific and }\end{array}$ & $\begin{array}{l}\text { Study of regional peculiarities of educational and scientific } \\
\text { systems, the market of educational services in the border } \\
\text { and cross-border space. Training of educational personnel } \\
\text { in the border area. Research work on the problems of } \\
\text { international education. }\end{array}$ \\
\hline $\begin{array}{c}\text { migration processes - } 27 . \\
\text { fhildren and youth in }-14 .\end{array}$ & $\begin{array}{l}\text { Migration motivation, migration attitudes; unaccompanied } \\
\text { children migrants and refugees; children in armed border } \\
\text { conflicts; educational migration. Training programs for } \\
\text { scientific and pedagogical staff on the problems of } \\
\text { migration, adaptation, multicultural education and } \\
\text { upbringing. }\end{array}$ \\
\hline
\end{tabular}

The development of cooperation in culture, education, science, mass information, health care, migration and social and labor relations has a direct impact on the creation of an atmosphere of mutual understanding and friendship between peoples (Komleva, 2017, pp. 13-34). The differentiation of the Russian border space determines the formation of various models and forms of cross-border cooperation, which is reflected in scientific works revealing the political content of international cooperation of Russia and CIS countries in the humanitarian sphere. Vardomsky L.B. (2008), Kashlev Y.B. (1988), Mikhailenko A.N. (2003), Pshenko K.A. (2001) and others make a great theoretical contribution to the study of individual areas of humanitarian cooperation in the field of education, science, culture. As pointed out in analytical studies of the Association of European Border Regions (AEBR), it is Russia that has a great cross-border potential for mutually beneficial cooperation in terms of economic integration and development of horizontal networks in the intercountry space. First, let us note that the concept of frontier has different semantics, which requires terminological clarification.

If in the original meaning the frontier was an area (boundary) between the developed and undeveloped lands of the western settlers, then in the interpretations of modern researchers the frontier is a zone of shifting borders in a broader sense. According to Zamyatina's definition, the frontier is characterized primarily as a zone of unstable equilibrium (Zamyatina, 1988, pp. 75-89). The historical experience of the development of frontiers and frontiers shows that the stability of any state is largely connected with the security of its state borders and is conditioned by the state of border security.

To study the activity of universities on the development of transnational education we systematized studies, which studied the factors that influenced the choice of students to study, educational institution and program, the orientation on the international rating of the university in transnational education (Dowling-Hetherington, 
2020), the difficulties that students encounter when studying in transnational education programs (Dai, 2020), etc.

The South of Russia is an economically developing macro-region, which is part of the dynamic development of a globally integrated economy, and it is a specific geographical space, embodying a diverse cultural heritage, confessional diversity with an intensively developing system of continuous education. The fundamental task of development of the South of Russia is the effective development of cross-border cooperation in education, its strategies, objectives, models in spatial development. This is since the process of globalization in the modern world, which has replaced the policy of "peaceful coexistence of states", has the primary goal of uniting states under a "common roof", their involvement in interdependent and mutually beneficial relations.

The Border cooperation is in the long-term interests of Southern Federal University (SFU) because it ultimately leads to the creation of a "belt of good neighborliness" along the perimeter of Russian borders. Also, border cooperation of SFU is an important factor in the development of interstate cooperation with Commonwealth of Independent States or CIS countries, which in the case of joint coordinated action by state and regional authorities has a positive impact on the intensification of integration processes between Russia and CIS.

In recent years, the South Federal University began to actively form the direction of development of cooperation in science and education based on cross-border approach and development of cross-border space with neighboring countries: the university consortium "Rubezhi Rossii" established centers, projects of Black Sea and Caucasus cooperation in education and science, etc. The team of authors has developed a scientific and educational project "Professional development of managerial staff (managers) in the field of education, science, cross-border and transboundary cooperation in education", which aims to cooperate in the training of leaders of educational and scientific organizations.

To develop the potential of cross-border cooperation, the South Federal University developed a project of master's degree programs based on the research and educational potential of the university, research of Bondarevskaya E.V. scientific school on the problems of migrant pedagogy and migration management in education. Using the results of theoretical analysis of scientific and rational discourses on globalization, regionalization, and cross-border cooperation in education, the objective was formulated to substantiate the productivity of designing master's programs at a federal university to develop cooperation in cross-border space. The article makes use of the results of theoretical analysis of numerous scientific and rational discourses on globalization, regionalization, and frontiers to substantiate the productivity of designing master's degree programs at a federal university to develop cooperation in the frontier space (Nogmova, 2018 , p. 126). The main directions of public policy in education and science in frontier space include internationalization, regionalization, and globalization; equity, accessibility, and quality; educational process, research.

The development of cross-border cooperation of SFU, as a topical problem of university management, is associated with the development and implementation of projects and programs designed to consolidate practical inter-regional cross-border cooperation and contribute to the fulfillment of strategic and thematic tasks of university cooperation at the international level. Using the results of theoretical analysis of numerous scientific and rational discourses on globalization, regionalization and frontiers, justify the productivity master's programs design at the federal university to develop cooperation in the border space. The main directions of public policy in education and science in frontier space include internationalization, regionalization, and globalization; equity, accessibility, and quality; educational process, research.

We formulated further directions for research and educational activities of the federal university in crossborder and transboundary space:

a) Creation of scientific and educational potentials of federal universities for the development of cooperation in cross-border geostrategic territories;

b) Analysis of innovative experience of general educational organizations, interdisciplinary research centers in the field of pedagogy, education to develop cross-border cooperation in education;

c) Substantiation and formulation of the main development directions of scientific and educational crossborder cooperation of South Federal University in the professional training of educational leaders (at the level of master's degree and additional professional education);

d) analysis of conditions and opportunities for the development and implementation of master's programs for training educational leaders, relevant to the formation of cooperation with the universities of border and 
cross-border space, including the consortium of universities " Rubezhi Rossii ".

It is suggested as a working hypothesis that Federal University, implementing the mission of education development in cross-border macroregion, has scientific and educational potential to expand cross-border cooperation in border and cross-border space of Southern Russia, the global dimension of South - South. Using the results of theoretical analysis of scientific and rational discourses on globalization, regionalization, and frontiers, justify the productivity of designing master's programs and programs of additional professional education at the federal university in order to develop cooperation in the border space.

The main areas of capacity building of the Southern Federal University for the development of cross-border cooperation in education are:

- Public policy in education and science in the border area include internationalization, regionalization, and globalization; equity, accessibility and quality; educational process and research;

- Creation of scientific and educational potential of federal universities for development of cooperation in cross-border geostrategic areas;

- Analysis of innovative experience of general educational organizations, interdisciplinary research centers in the field of pedagogy, studies to develop cross-border cooperation in education;

- Substantiation and formulation of the main directions of development of scientific, educational and outreach potential of cross-border cooperation of SFU in the professional training of educational leaders (at the level of master's degree and additional professional education);

- Systematization of conditions and opportunities for development and implementation of master's programs for education managers training, relevant to the formation of cooperation with the universities of the border and cross-border space.

We have formulated further directions for network research activities:

Research direction № 1. The educational space of the borderland of Southern Russia: projects and directions of development.

Research area № 2. Training of educational personnel (managerial personnel):

- Project of English-speaking master's program in the field of Pedagogical education (44.04.01) "Migrant pedagogy: migration management in education in modern conditions";

- The project of the English-speaking master program in the direction of Pedagogical education (44.04.01) "Border Regions in Transition: Teachers education and Leadership in education";

Research area № 3 consists of identifying the impact that the federal university's agenda for the development of cross-border cooperation in education and science had on the educational policy of these countries in relation to their joint activities in the border geostrategic territory, border space.

Research area № 4. Designing a system of transcultural education for foreign students in the border area of Southern Russia.

Research area № 5. Modern state and prospects of education and pedagogy development. Research area "Migrant pedagogy - interdisciplinary managerial and educational strategy". Scientific school of Evgenia V. Bondarevskaya. Migrant Pedagogy: Migrant Management in Education in Modern Conditions: Theory, Practice and Perspectives of Education, Multicultural Education, Career and Integration of Migrant Children in Russia and Abroad.

Research area № 6. Formation of an academic community of researchers from the South of Russia, united by a common historical past to carry out research directions for the training of educational personnel of the South of Russia and to establish intercultural partnerships.

In this project we rely on an interdisciplinary approach, if the potential of SFU and the scientific school of Bondarevskaya E.V. will allow realizing the educational and research opportunities of the federal university in the development of education in the multicultural border and cross-border space.

\section{CONCLUSION}

The process of increasing interconnection and interdependence of different countries, peoples and their cultures actualize the problem of neighboring. Back at the beginning of the twentieth century Simmel G. concluded that "a border is not a spatial fact with a sociological effect, but a sociological fact which is 
spatially formed" (Simmel, 1996, p. 607). Modern social practice convincingly confirms borders lose their barrier functions, and globalization not only reduces the barrier function of state borders, but also activates the formation of cross-border networks of informal and formal interaction and cross-border cooperation of universities. In this regard, we note the relevance of studies that have developed the concept of "space of flows" replacing "space of places"; human activity is now based on network interactions and is not confined to strictly confined "cages"-states and many others.

Under the conditions of global openness, the connections of educational systems in the border and crossborder space are changing, which implies theoretical understanding of these processes in the sphere of education. Globalization has a significant impact on the development of the humanitarian component of international relations in cross-border cooperation. Cross-border cooperation develops comprehensive and mutually beneficial ties of border territories of the Russian Federation with border regions of neighboring states in the sphere of education and science. Sustainable development of cross-border cooperation is determined by strategic plans, projects, and programs of socio-economic development, among which projects of cooperation in education in the border and cross-border space are topical.

For the new Russian border regions and districts, education and science can become an important stimulus for the development of border areas. The development of cross-border cooperation in Russia, as a topical problem of university management, is associated with the development and implementation of projects and programs designed to consolidate practical interregional cross-border cooperation and contribute to the fulfillment of strategic and thematic tasks of cooperation at the international level. Using the results of theoretical analysis of numerous scientific and rational discourses on globalization, regionalization, frontiers, justifies the productivity of designing master's programs in a federal university. Intensification of cross-border cooperation processes is also carried out by increasing attention to regional educational systems, universities, which is a multidisciplinary potential, innovative "growth points" in the development of crossborder cooperation in education are federal universities, among them, and the Southern Federal University.

The most important components of the cross-border region's potential include its educational potential, the university network of higher education, and its educational and scientific potential. The fundamental task for the development of the South of Russia is the effective development of cross-border cooperation in education, its strategies, objectives, models in spatial development. The Southern Federal University, as a university of a border subject of the Russian Federation, in which there are national interests of different states, aims to form a project base in the field of education management for joint solution of problems of migration processes in education, etc. The Southern Federal University defines the purpose of its development as international, cross-border and transboundary cooperation in the field of education, science, which is reflected in the proposed research problems until 2030.

Thus, cross-border cooperation in the field of education is an important component of international relations of the Russian Federation and is aimed at the establishment and development of a constructive dialogue between the subjects of cross-border cooperation of the Russian Federation and the subjects of crossborder cooperation of neighboring countries.

\section{REFERENCE LIST}

Castells, M. (1994). The Rise of the Network Society, London: Blackwell. p. 597.

The concept of cross-border cooperation in the Russian Federation, approved by Order of the Government of the Russian Federation of October 7, 2020 № 2577. https://www.garant.ru/products/ipo/prime/doc/74639793/

Dai, K.; Matthews, K. E., \& Renshaw, P. (2020). Crossing the 'bridges' and navigating the 'learning gaps': Chinese students learning across two systems in a transnational higher education programme Higher education research \& development, 18 (6). http://dx.doi.org/10.1080/07294360.2020.1713731.

Decree of the Government of the Russian Federation from 13.02.2019 N 207-r (23.03.2021 edited). On approval of the Strategy of Spatial Development of the Russian Federation for the period until 2025. http://www.consultant.ru/document/cons_doc_LAW_318094/

Dowling-Hetherington, L. (2020). Transnational Higher Education and the Factors Influencing Student Decision - Making: The Experience of an Irish University. Journal of studies in international education, 24 (3) http://dx.doi.org/10.1177/1028315319826320. 
Ivanov, S. (2020). Southern Federal University entered the consortium "Rubezi Rossii". Kommersant, September, 3.

Kashlev, Y.B. (1988). International Humanitarian Cooperation: Status and Prospects, M., p. 64.

Komleva, V.V. (2017). Russia in the context of the new world trends of internationalization of higher education. MID-Russian Bulletin of Social Sciences, 7. pp. 13-34.

Kotilko, V.V. (2016). Border regions of Russia and the experience of development of border areas abroad. Russian Academy of Sciences, Moscow: Peoples' Friendship University of Russia. p. 253.

Lukichev, G. (2004) Transboundary Education. Higher education today, 4.

Lukin A., Novikov D. Sino-Russian rapprochement and Greater Eurasia: From geopolitical pole to international society? Journal of Eurasian Studies, 12 (1). https://doi.org/10.1177\%2F18793665211000057

Mikhailenko, A.N. (2003). The Commonwealth of Independent States: Development Factors. M., p. 238.

Pratt M., Brown J. (2001). Boundaries, Territory and Postmodernity: Towards Shared or Separate Spaces? The Hague : Kluwer Law International. London. pp. 17-24.

Nogmova, A. S. (2018). Cross-border cooperation of the Russian Federation. Diplomatic Academy of the Ministry of Foreign Affairs of Russia. Moscow: Quant Media. p. 126.

Paasi, A. (2012). Border Studies Reanimated. Going Beyond the Territorial. Relational Divide. Environment and Planning, 44. pp. 2305-2309.

Pshenko, K. A. (2001). Commonwealth of Independent States: the formation of a common cultural and educational space. SPb.

Roos G., Voloshenko K.Y. \& Drok T.E. (2020). European countries' typology by the intensity of transboundary cooperation and its impact on the economic complexity level. GEOGRAPHY, ENVIRONMENT, SUSTAINABILITY. 13 (1). https://doi.org/10.24057/2071-9388-2019-66

Sebentsov, B. A. (2020). Cross-border cooperation on the EU-Russian borders: results of the program approach. GEOGRAPHY, ENVIRONMENT, SUSTAINABILITY, 13 (1). https://doi.org/10.24057/20719388-2019-136

Simmel, G. (1996). Izbrannoye. Moscow: Jurist, 2 (2). p. 607.

Spatial development strategy of the Russian Federation for the period up to 2025 (approved by the Government of the Russian Federation by Order No. 207-r of 13 November 2019.

The Concept of Cross-Border Cooperation in the Russian Federation (approved by the Government of the Russian Federation by Order No. 2577 - r of 7 October 2020.

UNESCO (2021). Futures of Education. https://en.unesco.org/futuresofeducation/

Vardomsky, L.B. (2008). Cross-border cooperation on Russia's 'new and old' borders. Eurasian Economic Integration, 1. pp. 90-108.

Zamyatina, N. Y. (1988). Zone of development and its image in the American and Russian cultures. Social Sciences and the present, 5. pp. 75-89. 